Article

\title{
An Isoxazole Derivative SHU00238 Suppresses Colorectal Cancer Growth through miRNAs Regulation
}

\author{
Haoyu Wang ${ }^{1,2,+}$, Yurui Ma ${ }^{2,+}$, Yifan Lin ${ }^{1}$, Jiajie Liu ${ }^{1}$, Rui Chen ${ }^{2}$, Bin Xu ${ }^{1,3, *}$ and \\ Yajun Liang ${ }^{2, *}$ \\ 1 Department of Chemistry, Qianweichang College, Shanghai University, Shanghai 200444, China; \\ hughie@shu.edu.cn (H.W.); miaomiao3327@126.com (Y.L.); ejay030201@163.com (J.L.) \\ 2 School of Life Science, Shanghai University, Shanghai 200444, China; Myr819374294@163.com (Y.M.); \\ rchen94@hotmail.com (R.C.) \\ 3 Innovative Drug Research Center, Shanghai University, Shanghai 200444, China \\ * Correspondence: xubin@shu.edu.cn (B.X.); yajunl2017@126.com (Y.L.); Fax: +86-21-66132830 (B.X.) \\ + These two authors contributed equally to this work.
}

Academic Editor: Yasuyoshi Miyata

Received: 12 June 2019; Accepted: 25 June 2019; Published: 25 June 2019

\begin{abstract}
Colorectal cancer (CRC) is a leading cause of cancer-related deaths worldwide. Isoxazoline and isoxazole derivatives represent an important class of five-membered heterocycles, which play a pivotal role in drug discovery. In our previous study, we developed a series of isoxazole derivatives with an efficient method. In this study, we evaluated their effects on tumor cell growth. HCT116 cells were treated with isoxazole derivatives; an cholecystokinin octapeptide (CCK-8) assay was used to calculate the $\mathrm{IC}_{50}$ (half maximal inhibitory concentration) of each derivative. Compound SHU00238, which was obtained by the copper nitrate-mediated $[2+2+1]$ cycloaddition reaction of olefinic azlactone with naphthalene-1,4-dione, has a lower $\mathrm{IC}_{50}$; we analyzed its inhibitory activity in further assays. Cell apoptosis was estimated by flow cytometry analysis in vitro. SHU00238 injection was used to treat tumor-bearing mice. We found that SHU00238 suppressed cell viability and promoted cell apoptosis in vitro. SHU00238 treatment significantly inhibited colonic tumor growth in vivo. Furthermore, we compared the miRNAs expression changes in HCT116 cells before and after SHU00238 treatment. MiRNA profiling revealed that SHU00238 treatment affected cell fate by regulating a set of miRNAs. In conclusion, SHU00238 impedes CRC tumor cell proliferation and promotes cell apoptosis by miRNAs regulation.
\end{abstract}

Keywords: colorectal cancer; isoxazole derivative; miRNAs; SHU00238; drug discovery

\section{Introduction}

Colorectal cancer (CRC) is a leading cause of cancer-related deaths worldwide [1]. Genetic and epigenetic alterations lead to the initiation of colorectal cancer. In addition, colorectal cancer is closely related with lifestyle, age, and inflammatory disease [2-6]. Most cases of colorectal cancer are sporadic and slowly develop through adenoma-carcinoma sequences within a few years [7]. The five-year relative survival rate is greater than $90 \%$ in stage I patients. However, the survival rate is slightly above $10 \%$ in stage IV patients [8-10]. There is a critical need for the investigation of novel, molecular-targeted therapeutics for CRC [11].

Isoxazole is a member of five-membered heterocycle; its adjacent position is composed of two heteroatoms, an oxygen atom and a nitrogen atom [12]. The featured structure makes it easy to form non-covalent interaction. Isoxazole compounds have a wide range of biological activities, including 
anti-cancer, anti-bacterial, anti-fungal, anti-viral, and anti-bacterial [13-15]. For instance, sulfisoxazole has been applied in urinary tract infections and risperidone has been approved to treat schizophrenia in adults [16]. In our previous study, we developed a novel, copper nitrate-mediated [2+2+1] cycloaddition reaction and provided an alternative route for the expedient synthesis of pharmacologically interesting 3-aryl substituted isoxazolines and isoxazoles [17]. With this method, we synthesized a series of isoxazole derivatives. In the present study, we determined their anti-tumor activities.

MicroRNAs (miRNAs, miRs) are 21-23-nucleotide, single-stranded RNAs that play tremendous regulatory roles in many biological processes; their dysregulation contributes to many diseases, including cancer [18-20]. MiRNAs regulate gene expression via binding to the $3^{\prime}$-untranslated region of genes [21,22]. Approximately two-thirds of protein-coding genes are regulated by miRNAs [23]. In this study, we synthesized 37 isoxazoline and isoxazole derivatives and determined their inhibitory activities in HCT116 cells. Among them, SHU00238 inhibited CRC cell viability more efficiently; Supplementary Material provides the preparation and spectroscopic data of SHU00238. In vitro and in vivo data revealed that SHU00238 suppressed CRC growth. Furthermore, we performed miRNA profiling with HCT116 cells treated with SHU00238. The data revealed that a set of miRNAs are significantly regulated by SHU00238, which regulated cell fate by targeting several cellular signaling pathways. Among the regulated miRNAs, miR-297, miR-30e-3p, miR-181d-5p, and miR-9-3p are known tumor regulators [24-29]. Therefore, the present study reveals that SHU00238 suppresses colorectal cancer growth through miRNAs regulation.

\section{Results}

\subsection{An Isoxazole Derivative SHU00238 has a Lower IC $C_{50}$ in HCT116 Cells}

The chemical structure of 37 candidate compounds is seen in Figure 1. We examined their inhibitory activities in HCT116 cells. Preliminary data showed that SHU00238, SHU00240, SHU00242, SHU00250, SHU00396, SHU03173, and SHU03174 could prohibit colonic tumor cells growth, as seen in Figure $2 \mathrm{~A}$. Furthermore, we determined the $\mathrm{IC}_{50}$ of these compounds with CCK- 8 assay. The results showed that SHU00238 inhibited HCT116 cell viability with a lower $\mathrm{IC}_{50}$ value of $0.3552 \mu \mathrm{M}$, as seen in Figure 2B. When we detected the cell apoptosis by AnnexV and PI (propidium iodide) staining, we found that SHU00238 treatment promoted cell apoptosis prominently, as seen in Figure 2C.

\subsection{SHU00238 Suppresses Colonic Tumor Growth and Cell Proliferation in Xenograft Mice Model.}

We explored the therapeutic effects of SHU00238 in tumor-bearing mice. HCT116 cells were injected subcutaneously in nude mice and SHU00238 administration was performed when the tumor size reached $500 \mathrm{~mm}^{3}$. Results showed that SHU00238 significantly reduced xenograft tumor volume, as seen in Figure 3A,B. In addition, we detected the expression of proliferation biomarkers in tumor tissues with immunohistochemical analysis. Ki67 and PCNA (Proliferating cell nuclear antigen) staining revealed that tumor cell proliferation was prominently reduced after SHU00238 treatment, as seen in Figure 3C. 

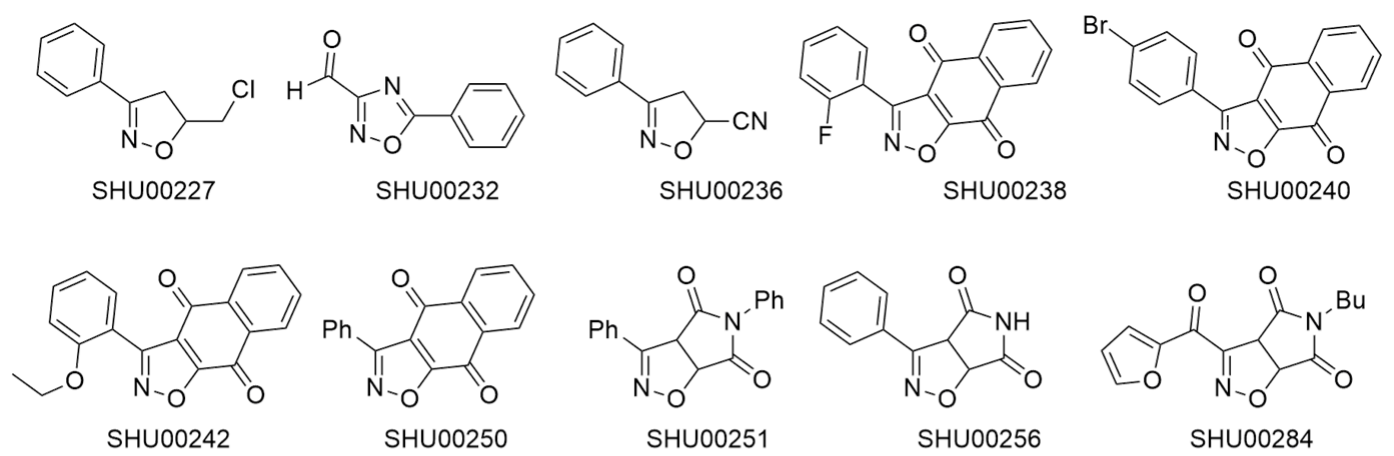<smiles>O=C(O[Ga])C1=NOC2C(=O)N(C3CC3)C(=O)C12</smiles>

SHU00285<smiles>NC(=O)c1cc(C(=O)c2ccccc2)no1</smiles>

SHU00290
$\sum_{N-O}^{O}$

SHU00317

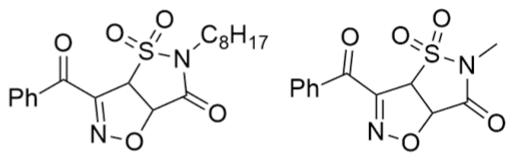

SHU00320

SHU00324<smiles>CC(C)(C)OC(=O)C1=NOC2C(=O)N(Cc3ccccc3)C(=O)C12</smiles><smiles></smiles><smiles>NC(=O)C1ON=C(C(=O)c2ccccc2)C1C(N)=O</smiles>

SHU00343

$\prod_{\mathrm{N}-\mathrm{O}}^{\mathrm{Ph}}-\mathrm{COOBn}$<smiles>O=C(c1ccccc1)C1CC(C(=O)c2ccccc2)ON1</smiles>

SHU00359<smiles>CN1C(=O)C2ON=C(c3ccc4ccccc4c3)C2(O)S1(=O)=O</smiles>

SHU00393
SHU00378<smiles>C#CCN1C(=O)C2ON=C(c3ccccc3)C2C1=O</smiles>

SHU00394<smiles>O=C(O[Ga])C1=NOC(S(=O)(=O)O)C1</smiles>

SHU00347

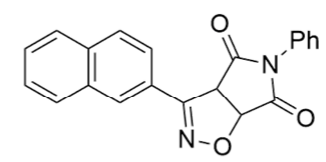

SHU00395<smiles>O=C1C2ON=C(c3ccc(Br)cc3)C2C(=O)N1c1ccccc1</smiles>

SHU00398

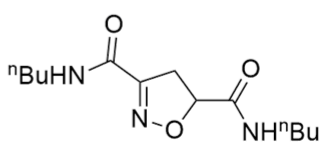

SHU00349<smiles>CC(=O)c1ccc2c(c1)c(C(C)(C)C)nc1ccccc12</smiles>

SHU00590<smiles>Cc1ccc2nc(C(C)(C)C)c3ccccc3c2c1</smiles>

SHU00625

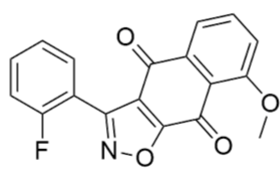

SHU03173

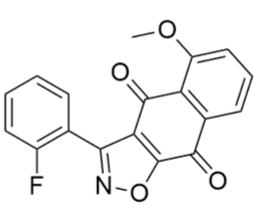

SHU03174

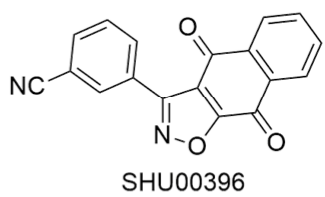<smiles>Cc1ccc2nc(-c3ccccc3)c3ccc(C)cc3c2c1</smiles>

SHU00589

Figure 1. Chemical structure of 37 candidate compounds. 
A

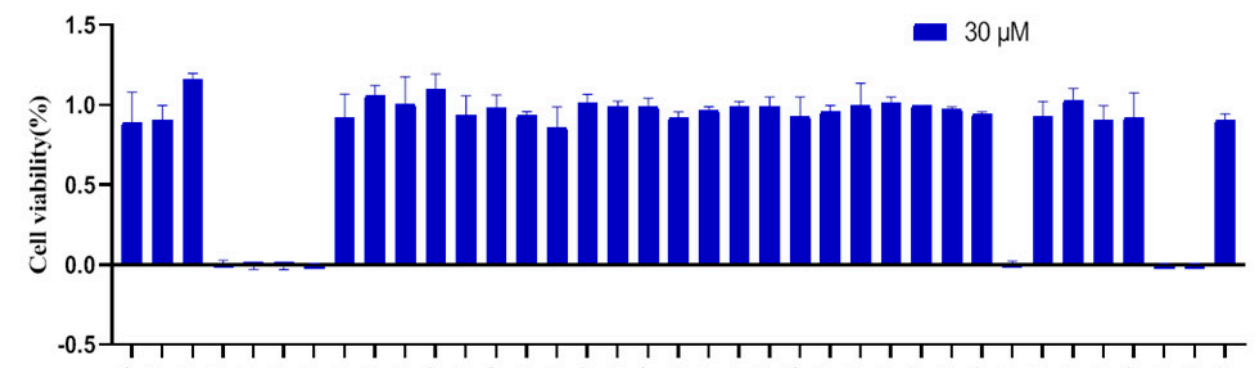

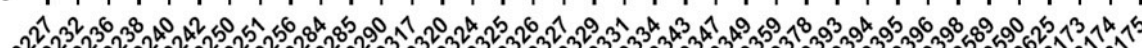

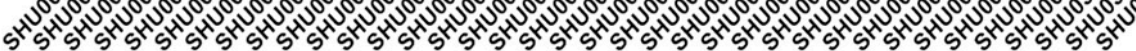

B

\begin{tabular}{cc} 
No. & $\mathrm{IC}_{50} / \mu \mathrm{M}$ \\
\hline SHU00250 & 0.4772 \\
SHU00238 & 0.3552 \\
SHU00240 & 0.9990 \\
SHU00396 & 1.0030 \\
SHU00242 & 1.0190 \\
SHU03173 & 0.9097 \\
SHU03174 & 1.4800
\end{tabular}

C
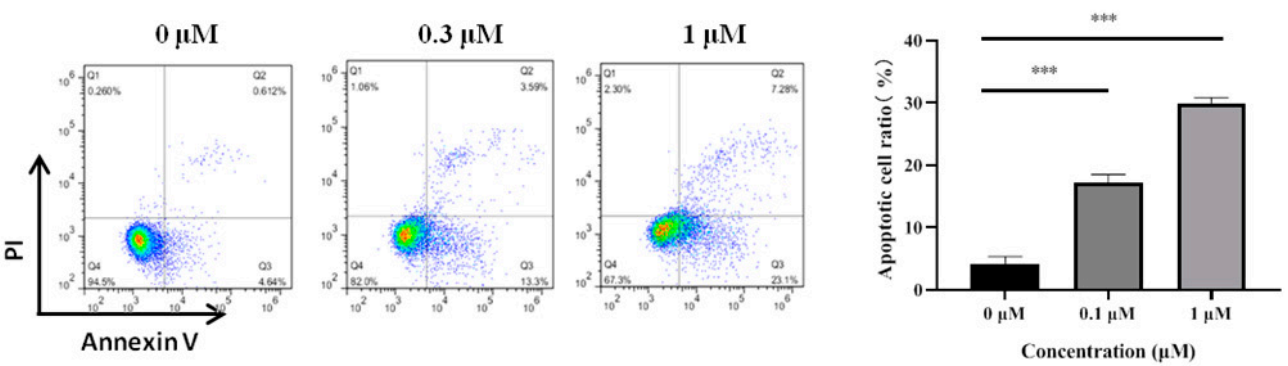

Figure 2. Seven compounds of 37 isoxazole derivatives suppress cell viability. (A) Cell viability analysis of HT116 cells treated with $30 \mu \mathrm{M}$ isoxazole derivatives, as determined by CCK-8 assay. (B) The $\mathrm{IC}_{50}$ value of seven effective compounds in HCT116 cells, as determined by CCK-8 assay. (C) Apoptosis analysis of HCT116 cells treated with $0.3 \mu \mathrm{M}, 1 \mu \mathrm{M}$ SHU00238 $(48 \mathrm{~h}, n=3)$. ${ }^{* * *}, p<0.001$. 
A

B
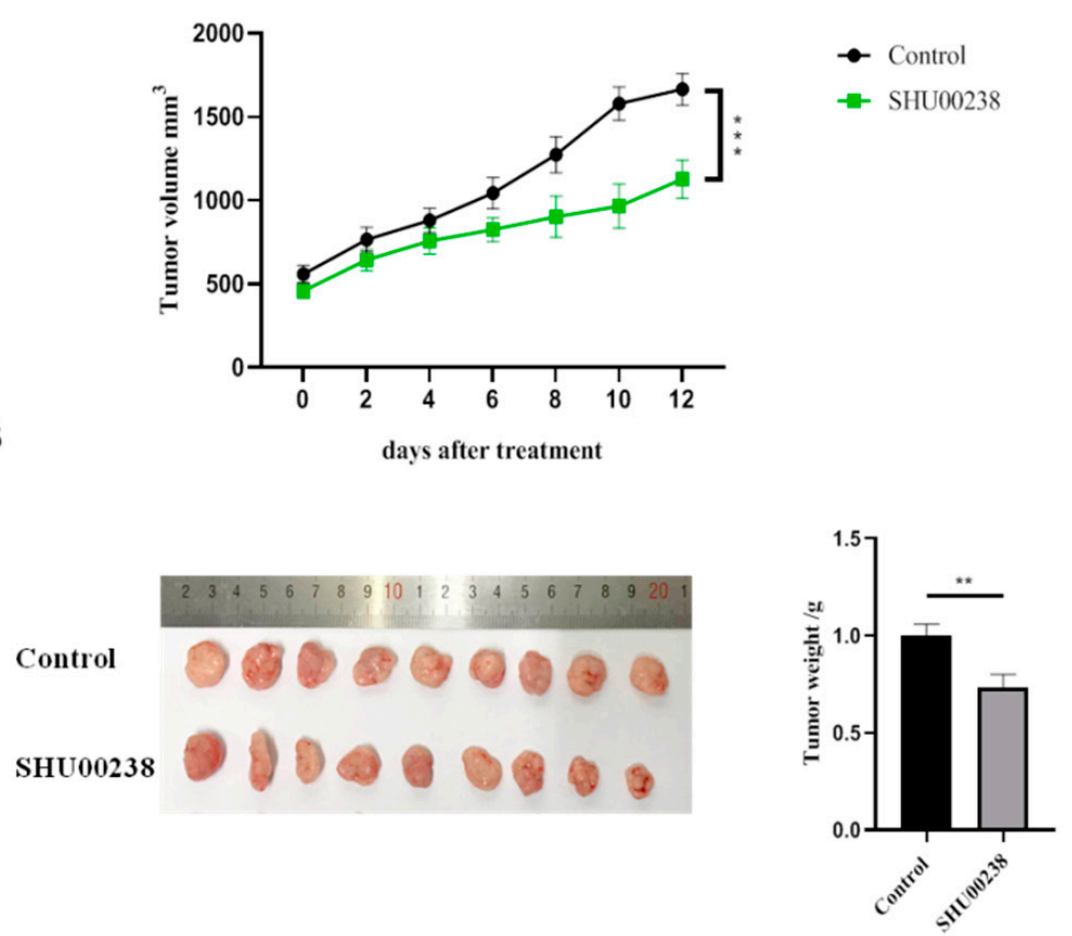

C
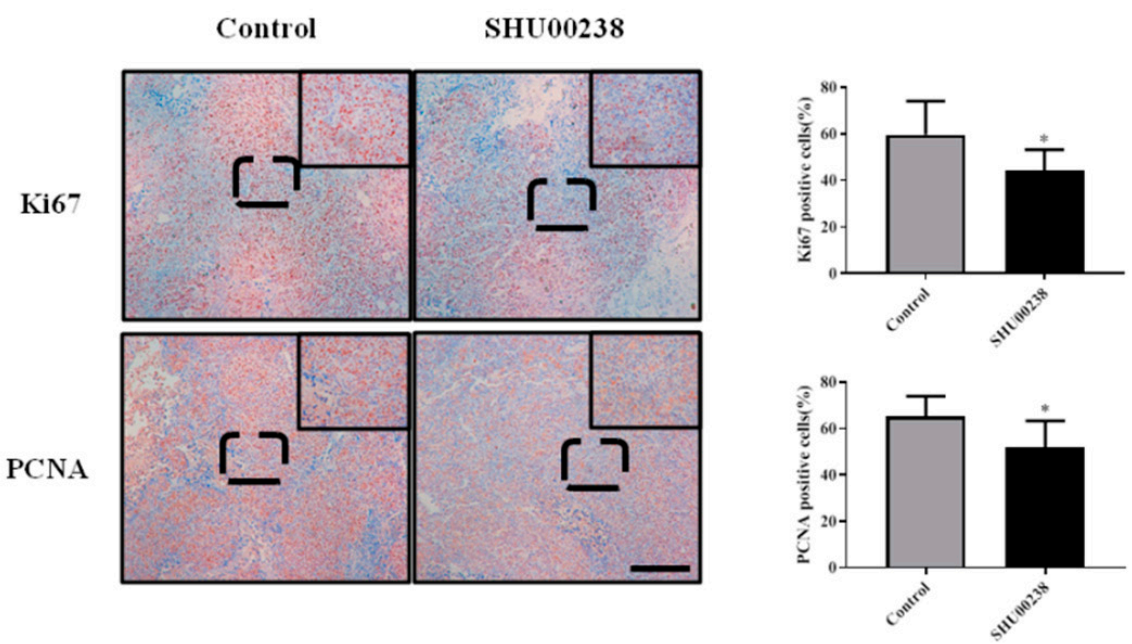

Figure 3. SHU00238 suppresses colonic tumor growth and cell proliferation in the xenograft mice model. (A) Tumor volume of control and SHU00238-treated mice $(40 \mathrm{mg} / \mathrm{kg}, n=9)$. (B) Tumors of control and SHU00238-treated mice at the end of experiment. (C) Ki67 and PCNA positive cells in tumor tissues. Scale bar, $200 \mu \mathrm{M}, *, p<0.05$.

\subsection{SHU00238 Treatment Affects Cell Fate by Regulating a Set of miRNAs}

To investigate the underlying mechanism of SHU00238 in tumor suppression, we performed miRNA microarray with HCT116 cells. A bioinformatics analysis revealed that SHU00238 treatment significantly changed miRNA expression. Among these miRNAs, the known tumor regulators were marked with underlines, as seen in Figure 4A. MiR-9-3p was identified as the tumor-suppressor miRNA and performed its functions by targeting TAZ expression in liver cancer [28]. MiR-181a-5p prevents cancer metastasis by targeting MMP-14 [27]. A blockade of miR-193a-5p increases the chemosensitivity of prostate cancer cells to docetaxel. MiR-30e-3p functions as a tumor suppressor 
through targeting Snail1 in clear cell renal cell carcinoma [29]. To explore the regulation of SHU00238 to cell fate, we analyzed the downstream genes of the regulated miRNAs, as seen in Figure 4B. GO(Gene Ontology) enrichment and KEGG(Kyoto Encyclopedia of Genes and Genomes) analysis revealed that cell fate-related signaling pathways were significantly changed by SHU00238 treatment, as seen in Figure 4C,D. Overall, our study demonstrates that SHU00238 suppresses colonic tumor growth in vitro and in vivo. SHU00238 affects cell fate by regulating a set of miRNAs.

A

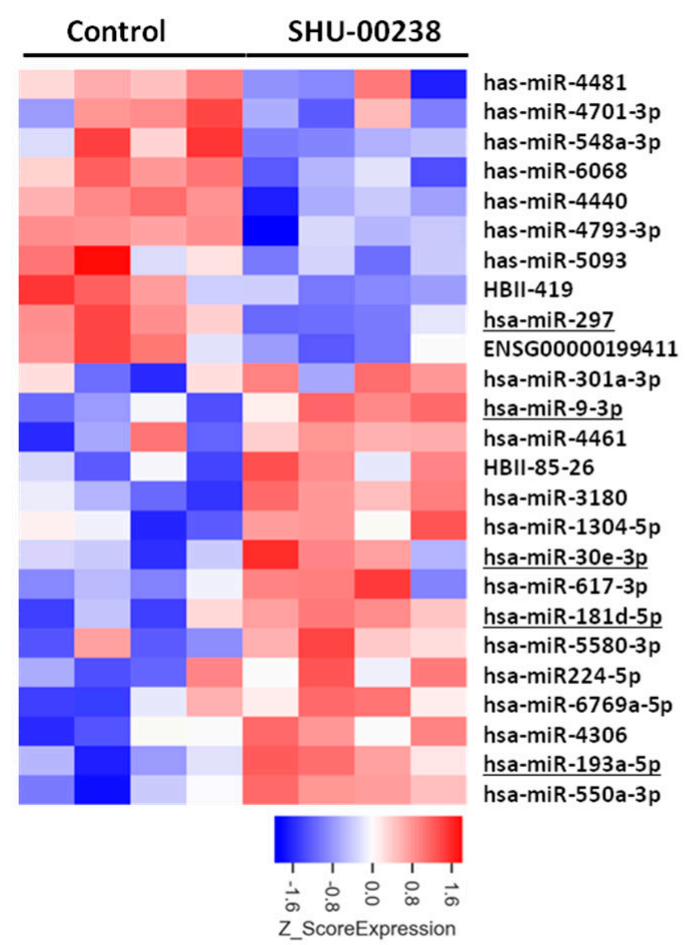

C

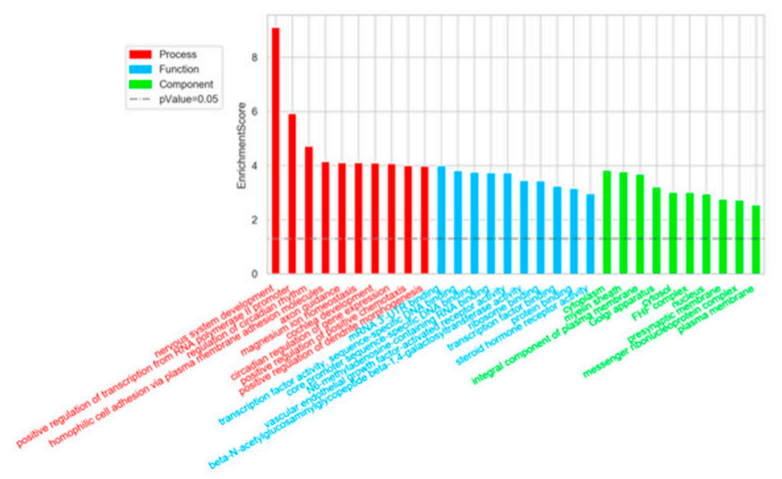

B

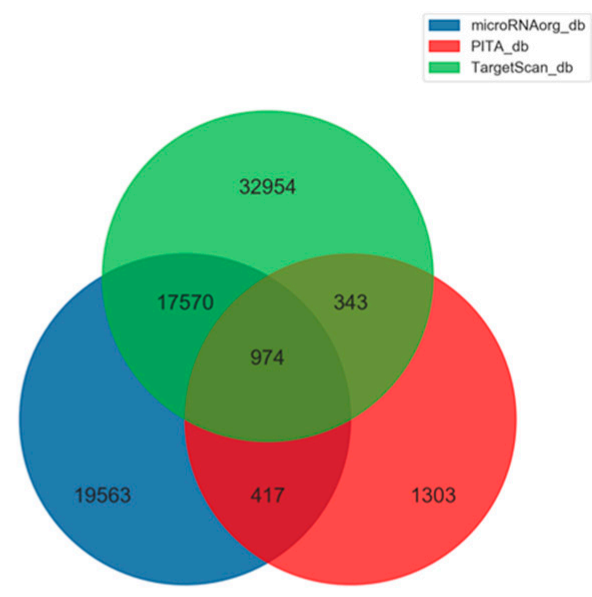

D

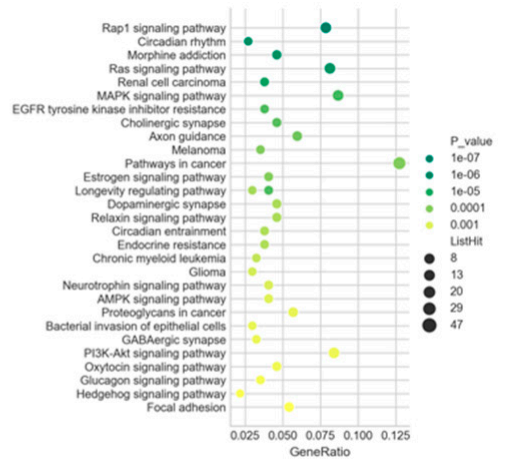

Figure 4. SHU00238 treatment affects cell fate by regulating a set of miRNAs. (A) Heatmap of the differential miRNAs. (B) Target genes of differentially expressed miRNAs from the intersection predicted with three databases (Targetscan, PITA, microRNAorg). (C) GO analysis and (D) KEGG analysis of the target genes. SHU00238 suppresses colonic tumor growth and cell proliferation in xenograft mice model.

\section{Discussion}

Isoxazole derivatives have a broad biological activities and play increasing important roles in drug discovery $[13,30]$. In our previous study, we developed an efficient route for the expedient synthesis of 
pharmacologically interesting 3-aryl substituted isoxazolines and isoxazoles [17]. In the present study, we determined their inhibitory activity in colonic cancer cells. Among them, SHU00238, SHU00240, SHU00242, SHU00250, SHU00396, SHU03173, and SHU03174, which all share a similarly featured structure, prevent tumor cell viability efficiently. The compound SHU00238 has a lower $\mathrm{IC}_{50}$ value in HCT116 cells, indicating its promising effects in tumor suppression.

Further analysis demonstrated that SHU00238 treatment promotes cell apoptosis in vitro. When we treated tumor-bearing mice with SHU00238, tumor volume and colonic tumor cell proliferation significantly decreased. Taken together, SHU00238 can inhibit colonic tumor growth both in vitro and in vivo, which indicates therapeutic application in tumor therapy. However, cancer is a complex disease; extensive studies are needed to determine the safety and metabolism of SHU00238 in tumor suppression [31].

To investigate the underlying mechanism of SHU00238 in tumor suppression, miRNAs profiling was performed [32-34]. Several known tumor regulators are significantly regulated by SHU00238 treatment. The functions of the other miRNAs in tumor progression are still to be elucidated. GO enrichment and KEGG analysis revealed that SHU00238 might affect cell fate by regulating several signaling pathways, such as Rap1 signaling pathway, Ras signaling pathway, MAPK signaling pathway, AMPK signaling pathway, pathways in cancer, and PI3K-Akt signaling pathway. However, further studies are needed to explain the mechanisms of SHU00238 treatment in tumor progression. Target screen works still need to be elucidated because isoxazoles are facilitate to form non-covalent interaction with other molecules.

\section{Materials and Methods}

\subsection{Cell Culture}

Colorectal cancer cell HCT116 is a human colon cancer cell line. HCT116 was bought from the Chinese Academy of Sciences Cell Bank. Cells was cultured in Dulbecco's modified Eagle's medium (DMEM, Corning, New York, NY, USA) with 10\% fetal bovine serum (FBS, CellMax, Shanghai, China) and $1 \%$ penicillin-streptomycin (PS, Gibco) at $37^{\circ} \mathrm{C}$ with $5 \% \mathrm{CO}_{2}$.

\subsection{Cell Viability Assay}

Cell viability was detected with cholecystokini ocatapeptide (CCK-8) kit (Bioworld, Shanghai, China). HCT116 cells were plated in 96-well plate at $2 \times 10^{5} / \mathrm{mL}$; cells were then treated with gradient-diluted compounds for $24 \mathrm{~h}$. Cells were incubated with CCK- 8 at $37^{\circ} \mathrm{C}$ for $1 \mathrm{~h}$; we then measured the optical density values (OD) 450 with microplate reader (Bio-Rad, Hercules, CA, USA). The $\mathrm{IC}_{50}$ of each compound was calculated using SPSS software by logit-transformed probit model.

\subsection{Cell Apoptosis Assay}

AnnexinV and PI Assay Kit (Beyotime, Shanghai, China) was used to measure the apoptosis level of HCT116 cells. Briefly, HCT116 cells were treated with DMSO or compound. After $24 \mathrm{~h}$, cells were resuspended in $100 \mu \mathrm{L}$ PBS. Cells were stained with Annexin V and PI at $4{ }^{\circ} \mathrm{C}$ for $20 \mathrm{~min}$ and then these samples were detected with flow cytometry (Beckman, Brea, CA, USA).

\subsection{Tissue Immunohistochemistry}

Xenograft tumor tissues were embedded in paraffin and sliced into $5 \mu \mathrm{m}$ sections. Samples were incubated in $65^{\circ} \mathrm{C}$ for $2 \mathrm{~h}$ and then were dewaxed and dehydrated. Samples were boiled for $10 \mathrm{~min}$ to unmask antigens. Next, samples were immersed in $0.3 \% \mathrm{H}_{2} \mathrm{O}_{2}$ for $10 \mathrm{~min}$ to destruct the endogenous peroxidase activity. We subsequently blocked the sections with $5 \% \mathrm{BSA}$, added $50 \mu \mathrm{L}$ primary antibodies against Ki67 (Abcam, 1:300, v/v, dilution) or PCNA (Proteintech, 1:300, v/v, dilution), and incubated overnight at $4{ }^{\circ} \mathrm{C}$. Secondary antibodies were added for $1 \mathrm{~h}$ at room temperature. Next, 
3,3-diaminobenzidine tetrahydrochloride (DAB) solution was used to amplify the signals. A total of 15 fields were randomly selected for each section under the microscope.

\subsection{Microarray Hybridization and Data Analysis}

Two group of total RNA from HCT116 with or without SHU00238 treatment were subjected to hybridization to Affymetrix miRNA4.0 arrays, performed by Shanghai OE Biotechnology Corporation. The microarray data was normalized according to the median intensity of each sample. Differentially expressed miRNAs were then identified through fold change as well as $p$-value calculated using a t-test. The threshold set for up- and down-regulated genes was a fold change $>=2.0$ and a $p$-value $<=0.05$. The miRNA array data have been deposited in GEO database. The accession number is GSE 132619.

\subsection{Mice and Treatment}

Athymic nude mice were purchased from the Cavens lab (Changzhou, China). All animal experiments were conducted according to institutional guidelines. Tumor-bearing mice were generated by injecting $3 \times 10^{6} \mathrm{HCT116}$ cells subcutaneously in eight-week-old mice. Two weeks later, compound (50 mM, 1:5 dilution, $40 \mu \mathrm{L}$ ) was injected intraperitoneally every other day. Xenograft tumors were dissected after 14 days. Tumor samples were fixed in 4\% PFA and stored in liquid nitrogen for later use. The protocol for this study was approved by the Animal Experiments Ethics Committee of School of Life Science in Shanghai University. All surgical procedures were performed under isoflurane anesthesia, and all efforts were made to minimize animal suffering and to reduce the number of animals used.

\subsection{Statistical Analysis}

All data were expressed as mean \pm SED. All statistical analyses were performed through IBM (Armonk, NY, USA) SPSS Statistics 20 and variables between groups were subject to either independent sample; a t-test was used for comparisons between two groups. One-way analysis of variance (ANOVA) was used for multiple comparisons. $p$-Values less than 0.05 were considered statistically significant.

Supplementary Materials: The following are available online.

Author Contributions: Conceptualization, B.X. and Y.L. (Yajun Liang); Formal analysis, Y.M., Y.L. (Yifan Lin) and J.L.; Project administration and formal analysis, H.W. and R.C.

Funding: This work was funded by the grants from National Natural Science Foundation of China (81800265 to Y. Liang, 21871174 to B. Xu) and Innovation Program of Shanghai Municipal Education Commission (No. 2019-01-07-00-09-E00008 to B. Xu).

Conflicts of Interest: The authors declare no conflict of interest.

\section{References}

1. Siegel, R.L.; Miller, K.D.; Jemal, A. Cancer statistics. CA Cancer J. Clin. 2019, 69, 7-34. [CrossRef]

2. Cappellani, A.; Zanghi, A.; Di Vita, M.; Cavallaro, A.; Piccolo, G.; Veroux, P.; Lo Menzo, E.; Cavallaro, V.; de Paoli, P.; Veroux, M.; et al. Strong correlation between diet and development of colorectal cancer. Front. Biosci-Landmrk 2013, 18, 190-198.

3. Abu-Remaileh, M.; Bender, S.; Raddatz, G.; Ansari, I.; Cohen, D.; Gutekunst, J.; Musch, T.; Linhart, H.; Breiling, A.; Pikarsky, E.; et al. Chronic inflammation induces a novel epigenetic program that is conserved in intestinal adenomas and in colorectal cancer. Cancer Res. 2015, 75, 2120-2130. [CrossRef]

4. Garcia-Anguita, A.; Kakourou, A.; Tsilidis, K.K. Biomarkers of inflammation and immune function and risk of colorectal cancer. Curr. Colorect. Canc. Rep. 2015, 11, 250-258. [CrossRef]

5. Xu, J.C.; Gao, C.; Lee, J.K.W.; Zhao, J.X. Pm2.5: A barrier to fitness and health promotion in china. J. Sport Health Sci. 2017, 6, 292-294. [CrossRef]

6. Wu, S.; Luo, Y.F.; Qiu, X.; Bao, M.X. Building a healthy china by enhancing physical activity: Priorities, challenges, and strategies. J. Sport Health Sci. 2017, 6, 125-126. [CrossRef] 
7. Dean, M. Cancer as a complex developmental disorder - nineteenth cornelius p. Rhoads memorial award lecture. Cancer Res. 1998, 58, 5633-5636.

8. Kuipers, E.J.; Grady, W.M.; Lieberman, D.; Seufferlein, T.; Sung, J.J.; Boelens, P.G.; de Velde, C.J.H.V.; Watanabe, T. Colorectal cancer. Nat. Rev. Dis. Primers 2015, 1, 15065. [CrossRef]

9. Moriarity, A.; O'Sullivan, J.; Kennedy, J.; Mehigan, B.; McCormick, P. Current targeted therapies in the treatment of advanced colorectal cancer: A review. Ther. Adv. Med. Oncol. 2016, 8, 276-293. [CrossRef]

10. Masuda, T.; Hayashi, N.; Kuroda, Y.; Ito, S.; Eguchi, H.; Mimori, K. Micrornas as biomarkers in colorectal cancer. Cancers 2017, 9, 124. [CrossRef]

11. Zhai, Z.; Yu, X.; Yang, B.; Zhang, Y.; Zhang, L.; Li, X.; Sun, H. Colorectal cancer heterogeneity and targeted therapy: Clinical implications, challenges and solutions for treatment resistance. Semin. Cell Dev. Biol. 2017, 64, 107-115. [CrossRef]

12. Barmade, M.A.; Murumkar, P.R.; Sharma, M.K.; Yadav, M.R. Medicinal chemistry perspective of fused isoxazole derivatives. Curr. Top. Med. Chem. 2016, 16, 2863-2883. [CrossRef]

13. Sysak, A.; Obminska-Mrukowicz, B. Isoxazole ring as a useful scaffold in a search for new therapeutic agents. Eur. J. Med. Chem. 2017, 137, 292-309. [CrossRef]

14. Jensen, M.R.; Schoepfer, J.; Radimerski, T.; Massey, A.; Guy, C.T.; Brueggen, J.; Quadt, C.; Buckler, A.; Cozens, R.; Drysdale, M.J.; et al. Nvp-auy922: A small molecule hsp90 inhibitor with potent antitumor activity in preclinical breast cancer models. Breast Cancer Res. 2008, 10. [CrossRef]

15. Montenegro, R.C.; Clark, P.G.K.; Howarth, A.; Wan, X.; Ceroni, A.; Siejka, P.; Nunez-Alonso, G.A.; Monteiro, O.; Rogers, C.; Gamble, V.; et al. Bet inhibition as a new strategy for the treatment of gastric cancer. Oncotarget 2016, 7, 43997-44012. [CrossRef]

16. Shiro, T.; Fukaya, T.; Tobe, M. The chemistry and biological activity of heterocycle-fused quinolinone derivatives: A review. Eur. J. Med. Chem. 2015, 97, 397-408. [CrossRef]

17. Lin, Y.; Zhang, K.; Gao, M.; Jiang, Z.; Liu, J.; Ma, Y.; Wang, H.; Tan, Q.; Xiao, J.; Xu, B. Copper nitrate-mediated synthesis of 3-aryl isoxazolines and isoxazoles from olefinic azlactones. Org. Biomol. Chem. 2019, 17, 5509-5513. [CrossRef]

18. Amirkhah, R.; Schmitz, U.; Linnebacher, M.; Wolkenhauer, O.; Farazmand, A. Microrna-mrna interactions in colorectal cancer and their role in tumor progression. Gene. Chromosome. Canc. 2015, 54, 129-141. [CrossRef]

19. Krol, J.; Loedige, I.; Filipowicz, W. The widespread regulation of microrna biogenesis, function and decay. Nat. Rev. Genet. 2010, 11, 597-610. [CrossRef]

20. Wang, L.J.; Lv, Y.C.; Li, G.P.; Xiao, J.J. Micrornas in heart and circulation during physical exercise. J. Sport Health Sci. 2018, 7, 433-441. [CrossRef]

21. Hayes, J.; Peruzzi, P.P.; Lawler, S. Micrornas in cancer: Biomarkers, functions and therapy. Trends Mol. Med. 2014, 20, 460-469. [CrossRef] [PubMed]

22. Catalanotto, C.; Cogoni, C.; Zardo, G. Microrna in control of gene expression: An overview of nuclear functions. Int. J. Mol. Sci. 2016, 17, 1712. [CrossRef] [PubMed]

23. Friedman, R.C.; Farh, K.K.H.; Burge, C.B.; Bartel, D.P. Most mammalian mrnas are conserved targets of micrornas. Genome Res. 2009, 19, 92-105. [CrossRef] [PubMed]

24. Yang, Z.; Chen, J.S.; Wen, J.K.; Gao, H.T.; Zheng, B.; Qu, C.B.; Liu, K.L.; Zhang, M.L.; Gu, J.F.; Li, J.D.; et al. Silencing of mir-193a-5p increases the chemosensitivity of prostate cancer cells to docetaxel. J. Exp. Cli. Can. Res. 2017, 36, 178. [CrossRef] [PubMed]

25. Xu, K.; Liang, X.; Shen, K.; Cui, D.L.; Zheng, Y.H.; Xu, J.H.; Fan, Z.Z.; Qiu, Y.Y.; Li, Q.; Ni, L.; et al. Mir-297 modulates multidrug resistance in human colorectal carcinoma by down-regulating mrp-2. Biochem. J. 2012, 446, 291-300. [CrossRef]

26. Ma, Z.; Qiu, X.; Wang, D.; Li, Y.; Zhang, B.; Yuan, T.; Wei, J.; Zhao, B.; Zhao, X.; Lou, J.; et al. Mir-181a-5p inhibits cell proliferation and migration by targeting kras in non-small cell lung cancer a549 cells. Acta Biochim. Biophys. Sin. 2015, 47, 630-638. [CrossRef] [PubMed]

27. Li, Y.; Kuscu, C.; Banach, A.; Zhang, Q.; Pulkoski-Gross, A.; Kim, D.; Liu, J.; Roth, E.; Li, E.; Shroyer, K.R.; et al. Mir-181a-5p inhibits cancer cell migration and angiogenesis via downregulation of matrix metalloproteinase-14. Cancer Res. 2015, 75, 2674-2685. [CrossRef]

28. Higashi, T.; Hayashi, H.; Ishimoto, T.; Takeyama, H.; Kaida, T.; Arima, K.; Taki, K.; Sakamoto, K.; Kuroki, H.; Okabe, H.; et al. Mir-9-3p plays a tumour-suppressor role by targeting taz (wwtr1) in hepatocellular carcinoma cells. Brit. J. Cancer 2015, 113, 252-258. [CrossRef] 
29. Wang, D.Y.; Zhu, C.; Zhang, Y.F.; Zheng, Y.N.; Ma, F.J.; Su, L.; Shao, G.J. Microrna-30e-3p inhibits cell invasion and migration in clear cell renal cell carcinoma by targeting snail1. Oncol. Lett. 2017, 13, 2053-2058. [CrossRef]

30. Zhu, J.; Mo, J.; Lin, H.Z.; Chen, Y.; Sun, H.P. The recent progress of isoxazole in medicinal chemistry. Bioorgan. Med. Chem. 2018, 26, 3065-3075. [CrossRef]

31. Hanahan, D.; Weinberg, R.A. Hallmarks of cancer: The next generation. Cell 2011, 144, 646-674. [CrossRef] [PubMed]

32. Schetter, A.J.; Leung, S.Y.; Sohn, J.J.; Zanetti, K.A.; Bowman, E.D.; Yanaihara, N.; Yuen, S.T.; Chan, T.L.; Kwong, D.L.W.; Au, G.K.H.; et al. Microrna expression profiles associated with prognosis and therapeutic outcome in colon adenocarcinoma. Jama-J. Am. Med. Assoc. 2008, 299, 425-436. [CrossRef] [PubMed]

33. Anvarnia, A.; Mohaddes-Gharamaleki, F.; Asadi, M.; Akbari, M.; Yousefi, B.; Shanehbandi, D. Dysregulated micrornas in colorectal carcinogenesis: New insight to cell survival and apoptosis regulation. J. Cell. Physiol. 2019. [CrossRef] [PubMed]

34. Shekari, N.; Baradaran, B.; Shanehbandi, D.; Kazemi, T. Circulating micrornas: Valuable biomarkers for the diagnosis and prognosis of gastric cancer. Curr. Med. Chem. 2018, 25, 698-714. [CrossRef] [PubMed]

Sample Availability: Samples of the compound SHU00238 are available from the authors. 